\title{
La romantización del Parnaso español. Fernando de Herrera, poeta oriental y cristiano
}

\author{
Mercedes Comellas \\ Universidad de Sevilla
}

Título: La romantización del Parnaso español Fernando de Herrera, poeta oriental y cristiano.

Resumen: La narrativa histórico-literaria del Romanticismo caracterizó la tradición poética espańola como oriental y cristiana. El orientalismo de su sustrato árabe se quiso localizar no solamente en la poesía popular, sino que también algunos de los poetas del canon fueron elegidos para demostrar la conexión del Parnaso español con esa pretendida raíz última de nuestra identidad. El caso más significativo y en el que más se insistió fue Fernando de Herrera. Se elogió el hebraísmo de algunas de sus canciones y se hizo especial hincapié en sus supuestos rasgos orientales y en la sublimidad de su musa cristiana.

Palabras clave: Fernando de Herrera, Romanticismo, orientalismo, cristianismo, sublimidad.

Fecha de recepción: 16/9/2020.

Fecha de aceptación: 5/12/2020.
Title: The Romanticization of the Spanish Parnassus. Fernando de Herrera, Oriental and Christian Poet.

Abstract: The historical-literary narrative of Romanticism characterized the Spanish poetic tradition as oriental and Christian. The orientalism of its Arab substrate was sought not only in popular poetry, but also some of the poets of the canon were chosen to demonstrate the connection of the Spanish Parnassus with that ultimate root of our identity. The most significant case, and the one on which most emphasis was placed, was Fernando de Herrera. The Hebraism of some of his odes was praised and special emphasis was placed on their supposedly oriental features and the sublimity of their Christian muse.

Key words: Fernando de Herrera, Romanticism, Orientalism, Christianity, Sublimity.

Date of Receipt: 16/9/2020.

Date of Approval: 5/12/2020.

\section{El ORIENTALISMO DE LA TRADICIÓN LITERARIA ESPAÑOLA}

El Romanticismo se quiso presentar desde sus primeros manifiestos como una nueva edad que en su dimensión literaria surgía del mismo seno de la espiritualidad cristiana. A la vez, su especificidad poética reivindicaba una tradición ajena a la predominante del clasicismo, tradición que encontró 
desde finales del siglo XVIII una fuente de nuevos valores artísticos en el progresivo interés por Oriente. Entre los pioneros de este cambio de paradigma, Abrams cita, como primer autor inglés que reformuló los conceptos fundamentales de la poética, el caso de William Jones, un eminente orientalista. Su antología de traducciones e imitaciones de poesía árabe, hindú y persa contenía un Essay on the Arts Called Imitative (1772), donde vuelve a las ideas de Longino sobre la inspiración y defiende el origen emocional e imaginativo — no imitativo- de la poesía. Para Jones, en los poetas orientales se observan de forma significativa los caracteres de espontaneidad y primitivismo ${ }^{1}$.

Casi contemporáneo de Jones, José Antonio Conde dio un impulso extraordinario al orientalismo espańol, mientras defendía el sustrato árabe de nuestra tradición literaria. Recogió sus tesis en la obra póstuma con la que culminaba décadas de estudios: su Historia de la dominación de los árabes en España (1820-1821) tuvo una extraordinaria difusión en Europa y sirvió para confirmar a la Península como un crisol cultural cuya principal herencia era la árabe y hebrea ${ }^{2}$. Con el propósito de demostrar "la gran influencia de la poesía arábiga en la castellana" ${ }^{3}$ incluye un buen muestrario de sus traducciones, "hechas de varias poesías árabes"4.

1 Meyer Howard Abrams, The Mirror and the Lamp: Romantic Theory and the Critical Tradition, London-Oxford, Oxford University Press, 1971, p. 87. El Discurso sobre la poesía de los orientales de Jones sirvió como introducción a las Poesías asiáticas puestas en verso castellano (1833) por el conde de Norońa, Gaspar María de Navas. A través de aquella traducción, conoció una importante difusión española.

2 Fue traducida al alemán (Karlsruhe, Braun, 1821 y 1824), al francés (Paris, Eymery, 1825), al italiano (Milano, Pirotta, 1836) y al inglés en 1854.

3 A dicha influencia se refiere en muchas ocasiones: "El estilo y expresión de la Crónica General de Don Alfonso X, el libro del Conde Lucanor y algunas obras del Infante Don Juan Manuel, como la Historia de Ultramar, están en sintaxis arábiga, y no las falta sino el sonido material de las palabras para tenerlas por obras escritas en muy propia lengua árabe" (José Antonio Conde, Historia de la dominación de los árabes en España: sacada de varios manuscritos y memorias arábigas, Madrid, Imprenta que fue de García, 1820-1821, pp. XIX-xx).

4 Conde incluye muchas de sus traducciones en la segunda y tercera parte de su obra, traducciones que fueron difundidas por la maurofilia de la época. Véase Sabih Sadiq, "La poesía árabe y los poetas españoles del siglo XIX. José Zorrilla (18291897)", Miscelánea de Estudios Árabes y Hebraicos, 45 (1996), pp. 281-294. Del mismo Sadiq: "La influencia de un poema árabe traducido por Conde de Noroña 
El florecimiento de los estudios orientalistas coincidió con las primeras historizaciones de la literatura española, en cuyos catálogos y colecciones iniciales participó el propio Conde 5 . No es por tanto de extrańar que el interés de los arabistas y hebraístas por nuestro pasado medieval influyese en la narrativa histórico-literaria y en el imaginario que se estaba forjando de la tradición poética española. Como bien explica Santiago Pérez Isasi, aquellos primeros historiadores no se limitaron a la "mera disposición cronológica de las obras y autores de la literatura espańola", sino que la articularon en torno a "una idea central, una guía narrativa":

Este mensaje central que debe vertebrar la historia de la literatura espańola es, por supuesto, el espíritu nacional, que se expresa en las obras literarias, y que el crítico debe descubrir e interiorizar antes de poder pretender construir una historia literaria. Es esta una exigencia previa para cualquier historiador de la literatura española, ya sea español o extranjero ${ }^{6}$.

De hecho, y como ha sido ya señalado muchas veces, en la construcción de esta "guía narrativa” de la historia literaria española, los autores extranjeros tuvieron un papel fundamental. Incluso puede considerarse que fundaron los conceptos sobre los que durante casi toda la centuria decimonónica se asentó la "idea” de la literatura española. Rosa María Aradra

en la obra del Duque de Rivas. «El espejismo» como esperanza perdida”, Anaquel de Estudios Árabes, 21 (2010), pp. 163-171. A finales del siglo XVIII y principios del XIX el Conde de Noroña había traducido por primera vez poesía oriental en las Poesías Asiáticas (publicadas solo en 1833).

5 Josep Lluís Martos, "La Real Academia Española y el Cancionero General del siglo XV: un proyecto editorial ilustrado", Boletín de la Real Academia Española, XCII (2012), pp. 221-253.

6 Santiago Pérez Isasi, "La historiografía literaria como herramienta de nacionalización en España (1833-1939)", Oihenart, 25 (2010), pp. 267-279 (p. 274). Vid. Xavier Andreu Miralles: El descubrimiento de España. Mito romántico e identidad nacional, Barcelona, Taurus, 2016, p. 38: "El historicismo romántico, un instrumento fundamental en el laboratorio decimonónico de las identidades nacionales, sirvió para apuntalar unas narrativas nacionales para las que era de vital importancia discernir los rasgos principales de unos caracteres nacionales nacidos de la «amalgama» de tan diversos principios. En este sentido, la distinción primordial entre Norte y Sur quedaba inscrita en los propios mitos fundacionales del Norte". 
observa que la visión crítica de los españoles sobre su propia literatura fomentó ya desde el siglo XVIII el interés por las foráneas y favoreció la influencia de perspectivas sobre el canon venidas de fuera ${ }^{7}$. Entre esas influencias, tuvieron un papel protagonista las herederas de la narrativa histórico-literaria generada por los hermanos Schlegel, de claro asiento geográfico. Friedrich Schlegel distinguía dos tipologías literarias, la clásica y la romántica, y dos ámbitos geográficos, el europeo y la franja ribereña colonizada por Grecia y Roma. Como zonas marginales "veía las tierras escandinavas, por una parte, y, por otra, la Península Ibérica” ${ }^{8}$. El espacio extraeuropeo, fundamento desde el que se explica el origen y la infancia del primero, se presenta como "fondo remoto de la identidad de Europa". Esta función la cumplían la cultura india, la cultura hebrea o la árabe, que se conciben conectadas con lo primario, lo auténtico y lo original, núcleo de valores schlegelianos ${ }^{10}$. La Península Ibérica desempeñaba en este diseño geoliterario un papel fronterizo entre Europa y Oriente que le hacía depositaria de una amalgama de elementos heterogéneos muy del gusto romántico. Esa posición le concede sus características culturales propias, que según los tópicos constitutivos del discurso geocultural europeo son su primitivismo (o anacronismo, según Cabo Aseguinolaza ${ }^{11}$ ), su com-

7 Rosa María Aradra, "Los procesos de formación del canon (reflexiones metodológicas sobre el canon literario español de los siglos XVIII y XIX", Signa. Revista de la Asociación Española de Semiótica 18 (2009), pp. 21-44 (pp. 27-28).

8 Hans Juretschke, "Las condiciones geográficas de la literatura y su marco europeo", en Friedrich von Schlegel, Obras selectas, eds. Hans Juretschke y Miguel Ángel Vega Cernuda, Fundación Universitaria Española, 1983, vol. II, pp. 470-473 (p. 471).

9 Fernando Cabo Aseguinolaza, "La dimensión geoliteraria de la historiografía literaria española", en El espacio en la narrativa moderna en lengua española, eds. Gabriella Menzel y Lászlo Scholz, Budapest, Universidad Ëotvös Loránd, 2003, pp. 8-25 (p. 16). Sobre esta distribución geoliteraria y sus consecuencias, véase también Xavier Andreu Miralles, op. cit., pp. 36-40; apunta Andreu Miralles que ya De l'esprit des lois de Montesquieu "dedicó mucho espacio a reflexionar sobre cómo el Norte, más frío. Era más idóneo para las repúblicas libres, el protestantismo y el individualismo, mientras el cálido Sur fomentaba el despotismo, el catolicismo y el gregarismo" (p. 47).

10 Hans Juretschke, op. cit., p. 470.

11 Fernando Cabo Aseguinolaza, "The European Horizon of Peninsular Literary Historiographical Discourses", en A Comparative History of Literatures in the Iberian Peninsula, eds. Fernando Cabo Aseguinolaza, Anxo Abuín González y César Domínguez, Ámsterdam, John Benjamins, 2010, I, pp. 1-52. 
posición oriental y su catolicismo. Las historias de la literatura española de Bouterwek (Geschichte der spanischen Poesie, 1804) y Sismondi (quien siguió fielmente al alemán en su De la littérature du midi de l'Europe, 1813) se encargaron de difundir por toda Europa los principios de aquella imagen de Espańa, que coincidía en parte - aunque no siempre en su veredicto final - con la afición orientalista de británicos y franceses, incluso con la reivindicación liberal de nuestro sustrato árabe ${ }^{12}$.

A estas tesis defensoras de la intrínseca mixtura de la cultura árabe e hispánica contribuyó el descubrimiento del aljamiado. Fue precisamente José Antonio Conde quien dio a conocer el aljamiado a Silvestre de Sacy, el más famoso arabista de aquella época; le envió en 1797 una lista de manuscritos de la Biblioteca de Palacio, donde trabajaba, "manifestándole que eran moriscos, escritos en castellano con caracteres arábigos"13. Sacy, más que Conde, sacó provecho de aquel descubrimiento y se convirtió en una figura muy reconocida. El periódico El Correo publica en 1831 un artículo que resume algunas de las ideas del orientalista francés sobre la necesidad de incorporar entre los valores de la crítica literaria los de la poesía árabe, que "no tiene menos derecho que la griega y la latina a ejercitar los talentos":

Los árabes, dijo el Sr. de Sacy, solo pintan en sus poesías los grandes efectos de la naturaleza, las pasiones del hombre [...]; se encuentra en ellos, como en los poetas europeos, conceptos nobles que elevan el alma [... que] transpiran todos los grandes afectos del carácter noble y fiero del árabe independiente [... En sus poesías] no se ven alteradas las varoniles bellezas sacadas de la naturaleza por una mezcla de pensamientos más delicados que sólidos, por adornos más ingeniosos que reales, y por expresiones más artificiosas que naturales ${ }^{14}$.

Estas virtudes que Sacy hace corresponder con la tradición oriental son las de la naturalidad frente al artificio y la autenticidad frente a la sutileza

12 Jesús Torrecilla, "El mito de Al-Ándalus", en España al revés. Los mitos del pensamiento progresista (1790-1840), Madrid, Marcial Pons, 2016, pp. 155-206.

13 Antonio B. Domínguez Prats, "José Antonio Conde (1766-1820), autor de Historia de la dominación de los árabes en España (Madrid 1820/21), descubridor de la literatura aljamiada, y primer historiador espańol moderno que usó las fuentes árabes en lengua original", Antigüedad cristiana, XXIII (2006), pp. 883-897 (p. 889).

14 "Idea de la poesía árabe", El Correo, 507 (7 de octubre de 1831), p. 2. 
o el ingenio. La "elevación de afectos” que produce esta poesía y en la que se "atraen los ánimos" a través de "una imaginación viva” coincide bien con aquella narrativa schlegeliana de los orígenes, en la que España (emocional e imaginativa $)^{15}$ se veía involucrada, no solo por su sustrato árabe, sino también por la participación de la tradición judía, que posee idénticos valores.

Así se observa comparando este artículo de Sacy con la reseña a los "Libros poéticos de la Biblia”, traducidos por González Carvajal, que salió en la Gaceta de Bayona y de la que Alberto Lista es probable autor ${ }^{16}$. En ella se apuntan las marcas originales de la poesía hebraica, que encajan a la perfección con las que se asignaban a la tradición espańola: primitivismo, conexión íntima con la lengua originaria (con todo lo que ello implicaba desde que se difundieron las tesis de Herder sobre la función de la lengua como cordón umbilical con la propia esencia de la nación $)^{17}$, desnudez y cierta rudeza que ańade vigor y energía a la expresividad, tan valorada en el Romanticismo. Por ello esa misma reseña alaba la traducción de Carvajal, que ha sabido respetar esos rasgos "del carácter de la poesía llamada oriental" y trasladarlos "en el nervio descarnado de la frase, en el corte de los periodos y en el desenlace aparente de sus miembros".

Dichos rasgos, como "se ha conocido luego", son propios

de todos los pueblos primitivos, que excitados por la sensación de los objetos y desconociendo las abstracciones que suministra el lenguaje perfeccionado, expresan sus ideas con esta individuación y

15 Jean de Vayrac, en su État présent de l'Espagne (1718), ya recogía la idea de que frente al francés, de naturaleza ordenada y racional, el español es un idioma que se rige por el sentimiento. Vid. Xavier Andreu Miralles, op. cit., p. 44.

16 Sobre la atribución de los artículos de Lista, véase Fátima Rueda Giráldez, "Revisión del legado de Alberto Lista y sus artículos literarios de El Censor", en Desde el XIX: reescrituras, traducciones, transmedialidad, eds. Marina Bianchi, Ambra Cimardi, Ricardo de la Fuente y José Manuel Gońi, Barcelona, Calambur, 2020, pp. 263-272.

17 Precisamente en una crítica a las poesías de Lista, el anónimo autor recuerda que "hasta los mismos pueblos salvajes o semi-salvajes tienen una especie de canto y lenguaje poético, siempre análogo a su clima, carácter y costumbres". "Literatura. Poesías de D. Alberto Lista”, El Universal, 230 (18 de marzo de 1822), pp. 3-4 (p. 3). La equivalencia entre la poesía primitiva y el pueblo que la cantaba fue una de las ideas herderianas de mayor recorrido en la crítica romántica europea. 
corporeidad favorable a la poesía; con atrevidas traslaciones a que obliga la escasez del idioma en su infancia, con ese desligamiento que ora nace del mayor dominio de la imaginación, ora de falta de las partes complementarias de la gramática ${ }^{18}$.

Esta descripción del estilo oriental, propio "de todos los pueblos primitivos" (nótese la equivalencia entre estilo oriental y poesía original), demuestra cómo la crítica romántica fue conectando entre sí una serie de atributos en alza, haciéndolos corresponder con una nueva categoría poética y un espacio histórico-literario hasta entonces sin definición, distinto del de la tradición clásica (única admitida como válida hasta entonces). Los primeros ejercicios historiográficos del Romanticismo, siguiendo aquella narrativa schlegeliana a la que nos referíamos, se fundamentaron precisamente en la división entre el clasicismo y otra tradición o tradiciones diferentes, ajenas territorialmente (la tradición oriental), anteriores al tiempo histórico (primitivas) o correspondientes a la renovación contemporánea (lo que acabaría llamándose Romanticismo).

Aquellos espacios no contaban en principio con ninguna caracterización definida, a diferencia de la tradición clásica, cuyo corpus, conceptos generales y fórmulas técnicas conocían un recorrido teórico casi tan largo como el de los propios textos. Ese nuevo espacio en blanco demandaba una formulación que resultó dispersa, controvertida y poco estable ${ }^{19}$.

18 Alberto Lista, "Sobre los libros poéticos de la santa Biblia, traducidos en verso y en prosa al castellano por D. Tomás José González Carvajal", Gaceta de Bayona, 94 (24 de agosto de 1829), p. 3. Las Lecciones sobre la Retórica y las Bellas Artes de Hugo Blair ya habían identificado los rasgos primitivos compartidos por todos los pueblos. Alberto Lista traslada la idea a su artículo "Carácter de la poesía oriental": "La primera literatura de todos los pueblos es esencialmente poética, porque es el idioma de la imaginación exaltada y de las pasiones vehementes no cohibidas por las leyes de la civilización. El ignorante ama y aborrece sin freno: para el ignorante todo es objeto de admiración y conmueve su fantasía. Así es que menos diferencia se encuentra entre los cantos osiánicos y la poesía hebrea, que entre los buenos poetas espańoles, italianos y franceses de fines del siglo XVIII". Vid. Alberto Lista, "Carácter de la poesía oriental", en Ensayos literarios y críticos, Sevilla, Calvo-Rubio y Compañía, 1844, vol. II, pp. 27-32 (p. 27).

19 Johann Nikolaus Böhl de Faber, "Del gusto en la poesía", en Pasatiempo crítico, Cádiz, Carreńo, 1820, p. 53: "La disputa" se resuelve "entre los que defienden un 
A configurarla podía ayudar especialmente esta categoría oriental (según Hegel el arte oriental era una fuente nueva para el arte moderno que enriquecía la "forma artística romántica" ${ }^{20}$ ) a la que, como demuestra la reseña de la Gaceta de Bayona, se asocian valores novedosos y contrarios a los de la clasicidad.

Frente al formalismo, la perfección o la sutileza, el estro oriental proporcionaba una mayor intensidad, cuya virtud Lista justifica con argumentos de naturaleza psicológica propios del sensismo ("excitados por la sensación de los objetos y desconociendo las abstracciones que suministra el lenguaje perfeccionado"). Con ellos insiste sobre la vinculación no abstracta, sino material, entre la palabra y su objeto, lo que en el Romanticismo se valoraba como una extraordinaria virtud por esa "persecución ontológica del objeto” en la que se empeñó la lírica romántica ${ }^{21}$ : la palabra, separada de la cosa, pugna por aferrarse a una carnalidad (musical, emocional, física) que, más allá de su condición de idea, la encarne como Verdad. En ese sentido, el hebreo, lengua que Dios entregó al hombre en el paraíso según la hermenéutica bíblica y cuyos nombres conectaban con el objeto nombrado, tenía una extraordinaria ventaja sobre los demás idiomas, de ahí su fuerza comunicativa.

Desde finales del siglo XVIII se convirtió en lugar común señalar la extraordinaria capacidad expresiva del hebreo y las lenguas semíticas. En palabras de uno de los redactores de El Europeo, considerada por muchos la primera publicación romántica española,

Lo extraordinario y que causa admiración es la fuerza de expresión de las citadas lenguas [semíticas]; no puede describirse hasta qué grado llega el encanto que produce su inflexión enérgica en el estilo sublime, y como su sencillez majestuosa anima la viveza de las imágenes atrevidas llenándolas de bellezas, que se deben exclusivamente

solo gusto puro y clásico fundado sobre reglas eternas e infalibles, y los que pugnan por la legitimidad de una variedad de gustos, modificados por los diferentes siglos y las distintas índoles nacionales".

20 Annemarie Gethmann-Siefert y Bernardette Collenberg-Plotnikov, introducción a G. W. F. Hegel, Filosofía del arte o Estética (verano de 1826), Madrid, Abada Editores-UAM, 2006, p. 23.

21 Paul de Man, "Structure intentionnelle de l'Image romantique", Revue internationale de philosophie, 14 (1960), pp. 69-70. 
a la lengua. No hay otras conocidas en el mundo que participen de estas prerrogativas ${ }^{22}$.

Por otra parte, según la teoría expresiva que fue forjándose en la última Ilustración y hereda el Romanticismo, la materialidad de las sensaciones contribuía a la perseguida comunicabilidad emocional. En ese sentido, la escasez, la pureza, el desnudamiento propios de las primeras etapas de la poesía, el contacto que permitían con la fisicidad de la voz aún no contaminada de abstracción, podían ser algo positivo; de ahí la valoración de la sencillez y espontaneidad de la tradición popular que acompañó a la renovación de la lírica a partir del Romanticismo.

\section{Herrera, poeta oriental}

Pero no solamente se defendió la condición oriental de nuestra tradición popular, sino que también algunos de los poetas del canon fueron elegidos para demostrar la conexión del Parnaso español con esa raíz última de nuestro carácter literario ${ }^{23}$. Con ello, los defensores de España reaccionaban a las acusaciones de los clasicistas franceses defendiendo la modernidad de nuestros rasgos singulares, pues incluso podían encontrase en el pasado

22 Carlos Ernest Cook, "Idiomas. Observaciones sobre ellos en general y los métodos para aprenderlos", El Europeo, II (10 de enero de 1824), 1, p. 8. Estas teorías sobre la lengua hebrea son herederas de las que durante el Renacimiento llegaban a afirmar que podía revelar hasta la esencia misma de los objetos nombrados: véase Sergio Fernández López, "La idea de la lengua sagrada en el apparatus de Arias Montano", en La impronta humanistica (ss. XV-XVIII). Saberes, visiones e interpretaciones, eds. Ana Castro Santamaría y Joaquín García Nistal, Palermo, Officina di Studi Medievali, 2013, pp. 81-88.

$23 \mathrm{Al}$ respecto, valga recordar la tradición de poesía bíblica en el Renacimiento, especialmente a partir de los Salmos. La ha trabajado brillantemente Valentín Núnez Rivera: Poesía y Biblia en el Siglo de Oro: estudios sobre los Salmos y el Cantar de los cantares, Madrid, Iberoamericana, 2010; "Poesía bíblica en el Siglo de Oro: paradigma y sintagma”, Ínsula, 865-866 (2019), pp. 7-10; "Arias Montano (y fray Luis de León) con el Cantar de los cantares: Paráfrasis, hermenéutica, persuasión”, en Traduire pour convaincre dans l'Espagne du Moyen Âge et du Siècle d'Or, ed. Elvezio Canonica, e-Spania Revue interdisciplinaire d'études hispaniques médiévales et modernes, 36 (junio de 2020). 
literario pruebas de haber sido nuestros poetas precursores de las nuevas tendencias. El caso más significativo y en el que más se insistió fue el de Fernando de Herrera. Dado que precisamente la expresividad y capacidad de emocionar de la poesía herreriana se habían puesto en entredicho tantas veces $^{24}$, la defensa de su orientalismo, con todos los valores expresivos que implicaba, resultó ser una fórmula muy conveniente para reivindicar su legado y encontrarle unas virtudes adaptadas a los nuevos criterios de valoración. Incluso para confirmarle como uno de los modelos más importantes que desde finales del siglo XVIII se buscaban en nuestro pasado lírico para enfrentar la crisis que la poesía española estaba atravesando.

Entre ellos, Herrera resultaba ser el vate épico que hacía falta para completar nuestra pobre tradición de cantos patrióticos, además de haber fundado, según los críticos del día, el lenguaje poético propiamente espańol $^{25}$. Y por ańadidura, le coronaba el estro oriental entonces de moda, que correspondía con la imagen más difundida de la Espańa exótica y con el profundo cristianismo de su musa. Por supuesto, en esa reivindicación no se incluía su poesía petrarquista, sino que se concentraba en las odas, y de ellas especialmente en dos: la dedicada "A la batalla de Lepanto" y "A la pérdida del rey D. Sebastián”. De todo el largo repertorio herreriano, solo estas dos obras (más alguna de las demás canciones, especialmente la dedicada "Al sueño") sostuvieron su fama romántica ${ }^{26}$.

Quizá el primer crítico en insistir en la influencia de la poesía hebrea (para el caso, bíblica) sobre Herrera fue Giovanni Battista Conti en su Colección de poesías castellanas traducidas en verso toscano e ilustradas

24 Mercedes Comellas, "Vida, verdad y poesía: la sinceridad de Herrera y la revisión romántica de su biografía”, Studi Ispanici, 46 (2021) (en prensa).

25 Mercedes Comellas, "Fernando de Herrera, un modelo clásico para tiempos románticos", en De Herrera. Estudios reunidos en el centenario de Versos (1619), eds. Juan Montero Delgado y Pedro Ruiz Pérez, Sevilla, Universidad de Sevilla, 2020 (en prensa).

26 Sobre la Canción I, véase: Francisco J. Escobar Borrego, "La pervivencia del himno pagano en la poesía de Fernando de Herrera”, en Sevilla y la literatura. Homenaje al profesor Francisco López Estrada, eds. Rogelio Reyes Cano, Mercedes de los Reyes Peña y Klaus Wagner, Sevilla, Universidad de Sevilla, 2001, pp. 247-259; y Jesús Ponce Cárdenas, "Somne, placidissime divum. I modelli della canzone herreriana $\mathrm{Al}$ Sueño", en Il pensiero e l'emozione. La rappresentazione del sogno nella letteratura, ed. Andreina Lavagetto, Pisa, Pacini, 2019, pp. 55-81. 
(1783). Allí argumenta lo que será la base de la fama herreriana como poeta oriental: Herrera "fue el primero que trasladó a la castellana el entusiasmo y grandeza de la hebrea, griega y latina" ${ }^{27}$. Para Conti, el Herrera de las canciones se separa de los modelos de la Antigüedad clásica y "fue el primero que en España ensayó la sublimidad de su numen en la imitación de la Poesía Hebraica, manifestando con cuánta felicidad desempeñó su empresa así este Himno [«Cantemos al Señor...»] como la Canción Elegiaca sobre la derrota en África del Rey D. Sebastián”, sin que haya ningún italiano de su tiempo que pueda competir con él ${ }^{28}$. La "Canción en alabanza de la Divina Majestad por la victoria del Señor Don Juan" supera los modelos grecolatinos,

subministrándole mucho mejor modelo de Poesía sublime los Libros sagrados que le indicaron el verdadero modo de alabar dignamente a la Divinidad. Se inflamó pues con el fuego de la Santa Escritura, y no solo enriqueció su fantasía con las vigorosas imágenes que tomó de tan grande original, sino que comunicó a su composición aquel aire de nobilísima franqueza que se advierte en ella ${ }^{29}$.

Las apreciaciones de Conti conocieron su mayor difusión cuando las hizo suyas Quintana, afirmando sin ápice de duda que "es en la oda elevada donde Herrera, feliz imitador de la poesía griega, hebrea y latina supo llenarse de su fuego y rivalizar con ella" ${ }^{30}$. Esta lectura de Herrera defendía también, desde Conti y Estala (maestro de Quintana), la sublimidad de la poesía herreriana ${ }^{31}$, condición que venía a coincidir con dicho carácter oriental. La opulencia verbal había quedado asociada a Oriente desde la

27 Juan Bautista Conti, Colección de poesías castellanas traducidas en verso toscano $e$ ilustradas, Madrid, Imprenta Real, 1783, p. LIII.

28 Ibidem, p. 243.

29 Ibidem, p. 241. Los estudiosos actuales sobre las fuentes bíblicas de la canción no suelen hacer referencia a sus predecesores dieciochescos y decimonónicos; vid. M. a Teresa Ruestes Sisó, "Sentimiento religioso y fuentes bíblicas en la canción por la victoria de Lepanto de Fernando de Herrera", Anuario de Filología, X (1984), pp. 237-258.

30 Manuel José Quintana, Poesías selectas castellanas desde el tiempo de Juan de Mena hasta nuestros dias, Madrid, Gómez Fuentenegro, 1807, vol. I, pp. XLV-XLVI.

31 Sobre la que ha escrito magistralmente Pedro Ruiz Pérez, "Vuelos y raptos poéticos: Estala, Herrera y lo sublime”, Bulletin Hispanique, 104, 1 (2002), pp. 391-423. 
oposición que hizo Quintiliano entre el estilo ático y el asianista. A finales del siglo XVIII, el concepto de lo sublime vino a renovar aquella vinculación entre la tradición lírica oriental y el estilo exuberante y elevado, pues la crítica contemporánea conectaba la sublimidad con el arte primigenio, simbólico y preclásico de la poesía hindú, la bíblica o la mahometana ${ }^{32}$.

Para gran parte de la historiografía romántica, el estrecho contacto con los árabes de la Hispania medieval había generado un sustrato particular del que se alimentó la singularidad de la literatura española, de ahí su naturaleza anticlásica, su tendencia al entusiasmo y la sublimidad, en definitiva, su intrínseco orientalismo. Según aquella formulación, Herrera podía ser considerado más español que Garcilaso no solo por el "patriotismo" de algunas de sus canciones o la nacionalización a la que había sometido la influencia italianizante ${ }^{33}$, sino porque comunicaba con las fuentes orientales hebraicas ${ }^{34}$, y también porque era más sublime y desmesurado que sus precedentes petrarquistas, rasgos que denotaban su profunda espańolidad.

Es el criterio que maneja Bouterwek, que siguiendo a Schlegel carga las tintas sobre el carácter romántico de Espańa. Schlegel precisamente había elogiado en su Lucinde (1799) la herreriana canción "Al sueño", de la que copia en la novela un pasaje en el original español ("y de licor

32 Así lo difundieron Blair, Herder, Hegel o Chateaubriand. El primero afirmaba en sus conocidas Lecciones: "Estoy por creer que las primeras edades del mundo, y el estado incivilizado y grosero de la sociedad, son muy favorables a las fuertes conmociones de la sublimidad. Entonces están los hombres más propensos a la admiración y al asombro. Al encontrarse con muchos objetos nuevos y extrańos para ellos, se acalora su imaginación y se exaltan sus pasiones. Piensan, y se explican con grandiosidad y con libertad" (Hugo Blair, Lecciones sobre la Retórica y las Bellas Letras, trad. José Luis Munárriz, Madrid, Ibarra, 1816, I, p. 77).

33 He tratado estos aspectos de la fama herreriana entre el último tercio del siglo XVIII y la primera mitad del XIX en Mercedes Comellas, "Fernando de Herrera, un modelo clásico para tiempos románticos", op. cit.

34 La cercanía del castellano a la primera lengua del hombre (que según se desprendía de la lectura bíblica de los humanistas era el hebreo) se había defendido ya con ardor en las disputas del Renacimiento sobre la jerarquía y el valor de las distintas lenguas, y fue argumento de fray Luis de León y Quevedo, entre otros. Vid. Sergio Fernández López, "El hebreo en la poesía y la prosa de Francisco de Quevedo", en Italia en la obra de Quevedo. Roma antigua y moderna, eds. M. ${ }^{a}$ José Alonso Veloso y Alfonso Rey, Santiago de Compostela, Universidad de Santiago de Compostela, 2013, pp. 183-206 (pp. 187-188). 
sagrado baña mis ojos tristes”), poniéndola en boca de un viejo que a las puertas de una cabaña solitaria, a la luz de la luna, la recita conmovido ${ }^{35}$. La Geschichte der spanischen Poesie und Beredsamkeit (1804) no demuestra sin embargo que a Bouterwek le conmoviese la lectura de Herrera, sino más bien coincide con la opinión de Böhl de Faber, que puede resumirse en los siguientes términos: "Herrera tiene una poesía sublime aunque no llega a conmover; lo elevado se halla más en los objetos que en el alma del poeta, y usa la metáfora de ser un río majestuoso y uniforme al que falta la novedad de la cascada" 36 .

A pesar de esa menos que mediana estima que ambos discípulos de Schlegel le profesaron, Herrera resultaba útil en la narrativa schlegeliana de España como el Oriente de Europa. Así, aunque Bouterwek leyó a Sedano y a Estala (según anota a pie de página) y los tiene como fuentes, lo que le interesa de Herrera en su recorrido histórico es proponer al poeta sevillano como ejemplo de orientalismo, marca que lo convierte en más español que sus antecesores italianizantes. No lo valora en absoluto como seguidor de Píndaro, pues en aquella intención de imitarle confundió - piensa - elevación con pretenciosidad ("wo er erhaben sein soll, [war] nur pretiös" ${ }^{37}$ ). No le distingue tampoco su sublimidad, sino su gusto oriental, alambicado. Era demasiado espańol para gustar de la simplicidad del primer petrarquismo ("aber er war zu sehr Spanier, um sich in einer solchen Simplizität zu gefallen”) ${ }^{38}$, de ahí que, frente a la pureza

35 Friedrich Schlegel, Lindor, Seitenstück zur Lucinde, von Schlegel, Mainz und Hamburg, Gottfried Vollmer, 1801, p. 127: "Plötzlich tönt mir von einer entfernten einsamen Hütte ein langsamer ernster Gesang, begleitet von einer Laute entgegen, ich nähere mich der Hütte - ich höre das spanische Lied des Herrera an den Schlafwie klagend wurde die Stimme bei den Worten: «y de licor sagrado bańa mis ojos tristes». Ich konnte dem geheimen Zuge nicht widerstehen, ich ging auf den Sänger zu. Auf einer Bank unter dem offnen Fenster saß ein bejahrter Mann, der Mond glänzte an seinem weißen Haar”. La canción se había incluido en la breve selección del Parnaso español de Sedano. Es muy probable que Schlegel la leyera allí.

36 Belén Molina Huete, "La Floresta de rimas antiguas castellanas de Böhl de Faber: proyecto antológico y canon romántico", en Gramática, canon e historia literaria: estudios de Filología española entre 1750 y 1850, coords. Victoriano Gavińo Rodríguez y Fernando Durán López, Madrid, Visor Libros, 2010, pp. 289-326 (p. 302).

37 Friedrich Bouterwek, Geschichte der spanischen Poesie und Beredsamkeit, Göttingen, Rower, 1804, p. 229.

38 Ibidem, p. 238. 
italiana, haya empleado un lenguaje más rebuscado, con tropos extraños y singulares que sin embargo eran del gusto del público español, acostumbrado a la tendencia oriental propia de su carácter nacional ${ }^{39}$.

La importante transmisión de la obra de Bouterwek aseguró la resonancia de estas valoraciones, y así para Sismondi la literatura española, a diferencia de las demás de Europa, es oriental; entre sus autores principales, "Herrera enriqueció prodigiosamente el lenguaje poético, con voces gráficas, con giros desconocidos hasta entonces y tomados en gran parte de la poesía oriental, cuyas bellezas le eran tan familiares" ${ }^{20}$. También la hispanística británica recibió la influencia de estas ideas: para Jeremiah Holmes Wiffen, editor de Garcilaso, como para muchos otros críticos contemporáneos, el sobrenombre de Divino lo debe a las odas, a su entusiasta imitación de Píndaro y de los profetas bíblicos:

In the Ode to Don John of Austria, the Hymn on the Battle of Lepanto, and his Elegiac Ode to King Don Sebastian, animated with the same fire as the hymn, but much more beautiful, we trace the successful study of Pindar and the Hebrew prophets, and recognise the sublime sentiment, the glowing imagery, the bold and ornamented diction, the vivid march and harmony of verse, which obtained for him, among his contemporaries, the surname of the Divine ${ }^{41}$.

También lo alaba Thomasina Ross en su traducción al inglés de la obra de Bouterwek; menos dura con Herrera que el alemán, matiza su opinión en una nota, aclarando que en "his ode on the battle of Lepanto, the style of the Hebrew psalms is imitated with happy effect" ${ }^{42}$. Henry Hallam, en su Introduction to the Literature of Europe in the 15th, 16th, and 17th Centu-

39 Ibidem, p. 239.

40 Jean Charles Simonde de Sismondi, De la littérature du midi de l'Europe (1813), traducción al español de José Lorenzo Figueroa, Historia de la literatura española desde mediados del siglo XII hasta nuestros días, principiada a traducir, anotar y completar por José Lorenzo Figueroa y proseguida por José Amador de los Ríos, Sevilla, Álvarez y Compañía, 1841, p. 378.

41 Jeremiah Holmes Wiffen, “Castilian Poetry”, Foreign Review, I (1828), pp. $44-84$ (p. 64).

42 Thomasina Ross, nota a su traducción de Friedrich Bouterwek, History of Spanish and Portuguese literature, translated from de original German by Thomasina Ross, London, Boosey and Sons, 1823, vol. I [Spanish Literature], p. 234. 
ries (1837-1839), afirma a su vez que los poetas petrarquistas españoles pertenecen a la escuela italiana y eran más traductores que originales, abandonando con aquella moda "the indigenous style of Castile" ${ }^{43}$. Frente a aquellos imitadores del estilo italiano, la riqueza de la frase de Herrera, "derived in some measure from the study of Pindar, or still more, perhaps, of the Old Testament" ${ }^{44}$, coincidía con esa manera más española, expansiva e hiperbólica, de chocantes metáforas. No hace falta insistir en la extraordinaria difusión de estas ideas en la hispanística europea, que llega incluso a impregnar la lectura de Herrera que hizo Karl Vossler: en el poeta sevillano descubre una "inmovilidad oriental y mística" ${ }^{4}$.

Entre los historiadores españoles también se insistió durante este tiempo en la imitación herreriana de la poesía bíblica, que, a pesar de ser una parte muy pequeña de su producción, se consideraba ahora la más importante. Mendíbil y Silvela insisten en que "[f]ue también el primero, al menos entre nosotros, en la imitación de la poesía sagrada” 46 . Según la Espagne poétique (1826) de Maury, "Herrera fut le premier qui accorda la lyre moderne au chant hébraïque" ${ }^{4}$. Y Lista, en su comentario a la canción "A la batalla de Lepanto", estudia detenidamente "el giro oriental de su elocución”48.

43 Henry Hallam, Introduction to the Literature of Europe in the 15th, 16th, and 17th Centuries, London, John Murray, 1837, vol. 2, p. 36: "In their odes, epistles, and sonnets, the resemblance of style, as well as that of the languages, make us sometimes almost believe that we are reading the Italian instead of the Spanish Parnaso. There seem however to be some shades of difference even in those who trod the same path. The Castilian amatory verse is more hyperbolical, more full of extravagant metaphors, but less subtle, less prone to ingenious trifling, less blemished by verbal conceits than the Italian".

44 Ibidem, p. 174.

45 Karl Vossler, La poesía de la soledad en España, Buenos Aires, Losada, 1946, pp. $92-$ 93. Vid. Juan Montero Delgado, Fernando de Herrera (1580-1980). Historia de la crítica, Tesis de Licenciatura (inédita), Sevilla, Universidad de Sevilla, Departamento de Literatura Española, 1981, p. 130.

46 Pablo de Mendíbil y Manuel Silvela, "Discurso preliminar", en Biblioteca selecta de Literatura española, o modelos de elocuencia tomados de los escritores más célebres desde el siglo XIV hasta nuestros dias, Burdeos, La Walle joven y sobrino, 1819, p. LVI.

47 Juan María Maury, Espagne poétique. Choix de Poésies castillanes [...] mises en vers français, Paris, Mongie, 1827, vol. I, p. 192.

48 Alberto Lista, "Lecciones de Literatura Española", en Vida, obra y pensamiento de Alberto Lista, ed. Hans Juretschke, Madrid, CSIC, 1951, pp. 418-465 (pp. 457- 
La tesis del orientalismo de la literatura española fue en ocasiones rebatida por algunos de nuestros eruditos, como en las notas que Lista incorpora a la reseña publicada en la Gaceta de Sevilla de 1811 al Essai sur la littérature espagnole $(1810)^{49}$. Allí negaba el sustrato árabe de la poesía española, argumentando que nuestro carácter nacional se forma durante el reinado de Carlos V, una vez que los musulmanes han abandonado la península y por tanto al margen de su influencia. Lo mismo hizo Alcalá Galiano en sus lecciones de la Universidad de Londres, dirigidas a un público británico para el que el orientalismo era la marca más significativa de nuestra literatura ${ }^{50}$, o José Lorenzo Figueroa en un apunte a su traducción de Sismondi ${ }^{51}$. Sin embargo, la idea penetró profundamente y el mismo Lista la acabaría incorporando a su explicación de la historia literaria española y de la poesía de Herrera, si bien en el caso particular del poeta sevillano el orientalismo lo entiende no tanto como marca del sustrato hispánico musulmán, sino como influencia de la poesía hebrea bíblica.

La imitación hebraísta herreriana la reconocía ya en uno de los artículos de la Gaceta de Bayona de 1828, donde el Divino se presenta como continuador del proyecto de dialecto poético de Juan de Mena y "genio superior, príncipe de nuestra poesía lírica, en la cual connaturalizó los rasgos atrevidos de la hebrea y los planes concertados de la latina" ${ }^{2}$. En el

458). En el comentario del poema seńala la "comparación propia del estilo hebreo" o "frase del estilo oriental", Ibidem, p. 459.

49 Vid. Manuel Contreras Jiménez, "Las Letters de John Talbot Dillon (1781) y el Essai sur la littérature espagnole (1810) en los inicios de la historiografía literaria española”, Esferas literarias, 1 (2018), pp. 155-187 (p. 173).

50 Antonio Alcalá Galiano, "An Introductory Lecture Delivered in the University of London, on Saturday, November 15", London, John Taylor, 1828. Traducción de M. ${ }^{a}$ del Carmen Heredia Campos en "La cultura española y el regeneracionismo liberal. El discurso de Antonio Alcalá Galiano en la Universidad de Londres de 1828”, Historia Contemporánea, 14 (2001), pp. 169-228.

51 José Lorenzo Figueroa, "Notas del traductor a la lección primera", en Jean Charles Simonde de Sismondi, op. cit., p. 29: "Tampoco es exacto lo que asienta el autor pocas líneas más arriba, cuando dice que la literatura espańola difiere esencialmente de las demás de Europa y que puede decirse que estas son europeas, mientras que aquella es oriental".

52 Alberto Lista, "Variedades", en Ensayos, ed. Leonardo Romero Tobar, Sevilla, Fundación José Manuel Lara, 2007, p. 105. La cursiva es mía. 
caso de la reseña antes citada a la traducción de los salmos por Carvajal (y salida también en la misma Gaceta de Bayona), el estilo bíblico o hebreo se presenta como un gusto particular por "las metáforas y comparaciones" 53 , tropos que en general se vinculaban a lo que se llamó entonces la "manera oriental" y que, para muchos críticos, tanto espańoles como extranjeros, caracterizaban nuestro particular estilo poético. En este caso, la traducción castellana de Carvajal no se compara con la imitación que hizo Herrera de ese estilo, sino que esos versos, "dulces y fluidos", están "dotados de las gracias nativas del habla y de una noble sencillez, semejante a la de Fr. Luis de León" 54 . Sin embargo, en otro de los artículos de Lista, "Carácter de la poesía oriental”, el protagonista es Herrera (“[e]l primero de nuestros poetas que enriqueció el Parnaso espańol con expresiones orientales fue el Divino Herrera" ${ }^{55}$ ). En estas páginas se observa cómo Lista acepta la tesis de Schlegel con respecto al orientalismo español, íntimamente ligado a las características de la sublimidad. Afirma Lista que "[d]e las literaturas modernas ningunas conocemos que hayan tomado tanto de la poesía oriental como la inglesa y la española" 56 , poniendo como ejemplo de esa influencia en el caso inglés a Milton, en el español, a Herrera. No es baladí la referencia al poeta inglés en una época en la que el mismo Lista se vio afectado por la moda de la poesía bíblica que tuvo el Paradise Lost como paradigma ${ }^{57}$. En realidad, el orientalismo español

53 Alberto Lista, "Sobre los libros poéticos de la santa Biblia, traducidos en verso y en prosa al castellano por D. Tomás José González Carvajal”, op. cit., pp. 3-4.

54 Ibidem, p. 3.

55 Alberto Lista, "Carácter de la poesía oriental”, op. cit., pp. 27-32 (p. 29).

56 Ibidem, p. 28.

57 Lista había practicado años atrás una suerte de épica bíblica en la estela miltoniana participando en un certamen convocado por la Real Academia de Buenas Letras de Sevilla, que propuso en 1799 como asunto el capítulo XIX del Génesis bajo el lema "La inocencia perdida: Canto en 80 octavas, o cerca de ellas, en que se describa la caída de los primeros padres", a imitación del concurso de la Real Academia Espańola sobre "La caída de Luzbel", ganado por Meléndez. Vid. Juan de Dios Torralbo, "Lista, Reinoso y Jovellanos: pioneros en la importación de poesía inglesa", en $E l$ Cid y la Guerra de la Independencia: dos hitos en la historia de la traducción y la literatura, ed. M. a Pilar Blanco, Madrid, Universidad Complutense, 2010, pp. 275-287 (p. 276); y M. a José Rodríguez Sánchez de León, "Temática bíblica y ficción en la literatura española del siglo XVIII”, en La Biblia en la literatura española, coord. Gregorio del Olmo, Madrid, Trotta, 2008, vol. III, pp. 81-118 (pp. 94-96). 
para él tenía menos relación con la posible influencia arábiga que con el estudio de los libros sagrados y la imitación de su poesía, esto es: por la conexión de nuestra tradición poética con la musa cristiana. De hecho, afirma que Herrera practicó ese estilo “solo en composiciones sagradas o a las cuales por lo menos se pudiese dar un colorido religioso" 58 . Se concentra en los hebraísmos de sus dos canciones más valoradas entonces, y en particular en la "Canción en alabanza de la divina majestad, por la victoria del señor don Juan”, que "está como empedrada de hebraísmos”, los cuales marca en bastardilla para mostrar a sus lectores cómo pueden imitarse los "rasgos de poesía oriental" 59 . A ella dedica la décima de las Lecciones de Literatura Española impartidas en el Ateneo ${ }^{60}$, afirmando que "[e]sta oda es, de cuantas hay en lengua castellana, la que más se acerca en el plan, el giro y en la elocución al carácter de la lírica hebrea”, pues "[s]in duda que Herrera quiso hacer muestra en esta oda de todo lo que podía acercarse nuestra poesía a la de los orientales" "61. Aquellas observaciones de Lista, y sobre todo el repaso que hace por los lugares imitados de la Biblia, tuvieron una larga resonancia y sirvieron tanto para el beneficio como para la reprobación de su autor. Por ejemplo, las recicló Virués para atacar al estudioso sevillano, en un comentario que sin embargo demuestra la difusión que ya habían conocido sus juicios:

Una de las opiniones formadas por tradición entre la juventud estudiosa [...] es la de que Herrera imitó en su estilo la poesía hebraica. El hecho, en mi juicio, (que en este caso es demostrativo), se reduce en la realidad a que Herrera copió y tradujo trozos grandes

58 El primero y el único de su siglo, según añade después: "Excepto Herrera, ninguno de los poetas de nuestro buen siglo se propuso enriquecer la poesía castellana con giros tomados de la oriental. [...] Calderón tiene algunos pasajes de la Escritura bien traducidos en sus autos sacramentales, mas no por eso hizo alarde del estilo oriental"; Ibidem, p. 31. Piensa diferente Adolfo de Castro, quien ve en los versos de Calderón vertidas "todas las galas del estilo oriental". Vid. Adolfo de Castro, "[Prólogo] El editor", en Poesías de D. Pedro Calderón de la Barca, con anotaciones, Cádiz, Imprenta, librería y litografía de la Revista Médica, 1845, pp. 11-16 (p. 16).

59 Alberto Lista, "Carácter de la poesía oriental”, op. cit., p. 30.

60 Alberto Lista, "Lecciones de Literatura Española, op. cit., pp. 418-465 (las citas son de pp. 457-462).

61 Ibidem, pp. 457-458. 
y pequeños de los poetas bíblicos; pero que en [...] esta copia o traducción, no hay una frase, ni una idea, que tenga ni aquel carácter, ni aquella singularidad, ni aquella sencillez, ni aquel laconismo, ni aquella velocidad, ni aquella robustez, ni aquella amplia reticencia de transiciones, y aun aquella armonía ${ }^{62}$.

Campoamor confirma en su Poética, con idéntico afán polémico, lo que Virués había ya querido demostrar en 1822, calcando casi sus palabras y concluyendo con una irónica traslación del comentario de Lista y una puya contra Herrera:

el divino Fernando de Herrera [...] ha escrito dos de sus más celebradas canciones, la de "A la pérdida del rey D. Sebastián" y la de "A la batalla de Lepanto", copiando de la literatura hebrea, en la segunda de dichas canciones, todas las frases y versos que pongo en letra bastardilla.

Tras una larga ristra de cursivas, cierra el pasaje herreriano con displicencia: "No traslado más, porque me canso de copiar una cosa tan árida, pero todas las estrofas se hallan empedradas de igual número de hebraísmos"63.

Escrito entre el comentario de Virués y el de Campoamor, el folleto "Fernando de Herrera" (1850), después de afirmar que la canción a la Victoria de Lepanto y a la de Don Sebastián "son las más dignas de estudiarse" de nuestra lírica, propone "mostrar cuáles son las frases y giros hebraicos con que enriqueció [Herrera] nuestro dialecto poético, para lo cual será suficiente señalarlos con bastardilla", concluyendo que "se ve, pues, que la canción está como empedrada de hebraísmos", influencia aún más importante en este poeta que en el mismo Fray Luis: "No dejaremos de notar que Fr. Luis de León, aunque trató asuntos religiosos, aunque tan sabio en la lengua hebrea, aunque tradujo el libro de Job y muchos salmos, tiene menos rasgos de poesía oriental en todas sus obras que esta sola canción de Herrera" ${ }^{64}$.

62 José Joaquín de Virués, El Cerco de Zamora. Poema en cien octavas en cinco cantos, seguido de un discurso crítico apologético, Madrid, Miguel de Burgos, 1832, pp. 59-60.

63 Ramón de Campoamor, Poética, Madrid, V. Suárez, 1883, pp. 55-57.

64 "Fernando de Herrera", en Hijos ilustres de Sevilla o colección de biografias de los naturales de esta ciudad que han sobresalido en santidad, ciencias, armas y artes, Sevilla, Juan Moyano, 1850, pp. 226-248 (pp. 245-248). 
El folleto debió ser obra de algún discípulo de Alberto Lista, que dejó en Sevilla y Cádiz un buen caudal de seguidores, hijos de esa "moderna escuela sevillana de literatura” de la que trató en su artículo de 1838. En él, Lista demuestra que para entonces ha aceptado plenamente la narrativa de los hispanistas extranjeros y así afirma que los poetas andaluces han "heredado de los árabes" un "carácter poético" singular, "más propio para sentir y para expresar sus propias ideas y pasiones" ${ }^{65}$. Dado el predicamento que tuvo entre su amplio número de alumnos, no es de extrañar que en las sucesivas historias literarias Herrera — padre de la primera escuela sevillana, según el mismo Lista - acabara convirtiéndose en cabeza de una "escuela oriental" andaluza, cuya definición y características irán incorporando nuevos matices. Entre los muchos textos que así lo defienden, es significativo el discurso que Joaquín Francisco Pacheco leyó en 1847 ante la Real Academia Española, respondiendo al de Fermín de la Puente. Si este traza un recorrido por la historia literaria andaluza en la que el componente oriental de la herencia musulmana tiene un papel protagonista, como también Herrera, jefe de la escuela sevillana, Pacheco progresa sobre ese trazado, presentando aquella herencia incluso como un regalo de la divinidad.

Después de conectar los tesoros de la arquitectura andalusí (reivindicados con ardor desde el Romanticismo) con los de la poesía ${ }^{66}$, hace uso de

65 Alberto Lista, "De la moderna escuela sevillana de literatura", Revista de Madrid, I (1838), p. 271: "Es un fenómeno literario muy digno de observación que, habiéndose distinguido tanto los poetas andaluces en varios géneros, han quedado sin embargo muy inferiores a los de Madrid y de otros puntos de España en la poesía dramática"; la explicación podría estar en la condición de Madrid como capital. "¿O bien esta pobreza de genio dramático procederá del carácter poético de los andaluces, heredado de los árabes, más propio para sentir y para expresar sus propias ideas y pasiones, que para fingirlas en otros personajes? El hecho es cierto: nuestros lectores adoptarán la explicación que les parezca más exacta”. La cursiva es mía.

66 Joaquín Francisco Pacheco, "Discurso de contestación [al de Fermín de la Puente]", Discursos leídos en las recepciones públicas que ha celebrado desde 1847 la Real Academia Española, Madrid, Imprenta Nacional, 1860, vol. I, pp. 310-329: "ese brillo tan oriental, tan suntuoso, tan desemejante a la índole de las rivales civilizaciones, ¿no os dice, repito, lo que era en sí verdaderamente la andaluza? ¿No os descubre el carácter de su poesía? ¿No os revela el secreto de su ser, el misterio de sus encantos? Si el Partenón explica a Sófocles, si el Colosseo traduce en piedra a Virgilio, ¿cómo no ha de verse en los grandes monumentos que cité más arriba la índole del canto 
los lugares comunes de la defensa del sustrato musulmán, instando a recordar el "estado de la Poesía castellana antes y después de la conquista de aquel territorio", y cómo "su dureza, [...] su rigidez, [...] su encogimiento" vino a reconstituirse con los cantares de "los sentimientos más delicados, y revestirse con las galas más fantásticas en el Romance morisco, que es el primero de los romances todos" 67 .

Según su versión de la historia literaria, esa verdadera naturaleza de la poesía andaluza que se descubre en la poesía árabe y en los romances fue abandonada en el Renacimiento ("cuyo abandono es el cargo más grave contra los introductores de la manera italiana"), y ello basta para "consignar el imponderable mérito con que restauró todo lo posible de su obra el divino Herrera, restituyendo a nuestra Musa el vigor, la armonía, la pompa, la riqueza, la entonación que nadie le sospechaba" ${ }^{68}$.

Los discursos de Pacheco y De la Puente, bastante anteriores a la Historia y juicio crítico de la escuela poética sevillana en los siglos XVI y XVII (1871) de Lasso de la Vega, confirman que antes del medio siglo, durante los años finales del Romanticismo, se había consagrado una "idea" de la tradición propia andaluza — frente a la castellana—, que defiende como propios los valores en alza y erige a un Herrera orientalizado en primera figura de su Parnaso. Porque si Herrera era un formalista, en la poesía andaluza (como en la de Oriente) "domina la forma", "es por lo común exterior"; sus principales genios —afirman De la Puente y Pachecoson Juan de Mena, Fernando de Herrera y Luis de Góngora "todos tres andaluces, todos tres nacidos a las orillas del Betis" ${ }^{69}$. Su esencia no es la

que se elevaba de las márgenes del Genil y del Guadalquivir, en medio de aquellas mares de delicias de Zahara y del Generalife?” (p. 323).

67 Ibidem, p. 323.

68 Ibidem, p. 328. Insiste varias veces en el papel de Herrera como restaurador de la verdadera poesía andaluza (cuya raíz musulmana ha defendido), y reivindica después al mismo Góngora como su segundo: "séame suficiente citar a Fernando de Herrera y a D. Luis de Góngora, para haceros conocer todo lo que debe el Parnaso español a la Musa del mediodía; y toda la influencia que ha ejercido el genio andaluz en esta vastísima literatura, que no se encierra sólo en nuestros límites peninsulares, sino que se dilata desde el Pirineo hasta los últimos confines del mundo transatlántico" (Ibidem, p. 326).

69 Ibidem, p. 327. Habría, pues, que adelantar la fecha a la que se refiere Begoña López Bueno en su atinado comentario sobre los estereotipos que se hicieron comunes en la 
de los pueblos del norte, que encarnan los personajes de Shakespeare y las nieblas de Albión, pues esa "poesía exterior, de forma, de brillo, de expansión [...], se complace en la dulzura, en la luz, en el deleite, un poco quizá más de lo justo en la amplitud, en el número, y en la arrogancia"70.

Otro de los discípulos de Lista, José Fernández Espino, también se preguntó "¿[p]or qué en los vates de Andalucía, ese constante anhelo de dar ensanche y galas a la dicción poética?”’1 incidiendo en esa intención de demarcar una identidad literaria andaluza (en la que además era posible cierta defensa de Góngora). Pero Fernández Espino, que como Alcalá Galiano no creía en la influencia del sustrato oriental, prefirió buscar una explicación en el determinismo climático ${ }^{72}$.

La Historia crítica de la literatura española (1861) de José Amador de los Ríos, que solo llegó hasta la época visigoda, no pudo desarrollar propiamente el papel del orientalismo en nuestra tradición literaria, aunque en sus volúmenes no deja de notarse el importante papel que concede en las diferentes épocas al "elemento oriental", a la influencia sobre nuestra tradición del "elemento hebraico-oriental", a los "decisivos rasgos del genio oriental", etc. ${ }^{73}$.

caracterización de la poesía sevillana. Vid. Begońa López Bueno, "Fernando de Herrera "gongoriza»: más sobre las estrategias del grupo sevillano (con Espinosa y Lope al fondo)", en La «Idea» de la poesía sevillana en el Siglo de Oro, coord. Begońa López Bueno, Sevilla, Universidad de Sevilla, 2012, pp. 287-318 (p. 296): “el panorama tan amplio y tan poco estructurado que trazó Ángel Lasso de la Vega y Argüelles en su Historia y juicio crítico de la escuela poética sevillana en los siglos XVI y XVII, Madrid, Imprenta de la Viuda e Hijos de Galiano, 1871, que por ser la primera monografía que gozó de cierta oficialidad en medios eruditos, se convirtió en referente para la reiteración de erróneos lugares comunes sobre la poesía sevillana, tales como pervivencia del elemento oriental, espíritu religioso, rivalidad con la escuela salmantina, influencia del medio, etc."

70 Ibidem, p. 329.

71 José Fernández Espino, Curso histórico-crítico de literatura española, Sevilla, Imprenta y librería Calle las Sierpes, 1871, p. 697.

72 "[L]a causa está en el clima y la feracidad de la naturaleza. El embeleso de un cielo purísimo, de un sol brillante que acalora la mente, de un suelo que sonríe por la amenidad de los árboles, de las fuentes y las flores, y por el balsámico aliento de céfiros apacibles, llenan de tal modo el espíritu de ideas y sentimientos, que se desbordan y derraman, a manera de torrente impetuoso, del corazón y de la fantasía del poeta: de aquí el necesitar mayor holgura para el colorido y gracia de la expresión" (Ibidem, p. 697).

73 Como Fernández Espino, también Amador de los Ríos coincide con Lista en se- 
Por su parte, Lasso de la Vega se detiene largamente en "la [escuela] sevillana, señalándose en sus tendencias desde un principio [...] el elemento poético oriental"74. Pero sobre todo aquella demarcación adquiere pleno protagonismo en los Principios de literatura general e Historia de la literatura española (1872) de Manuel de la Revilla, que distingue la sevillana-oriental entre las varias escuelas literarias españolas, resultantes de diferentes influencias recibidas (entre las que "el predominio del arte oriental es un hecho incontrovertible"). Durante el reinado de los Reyes Católicos, “[e]l arte greco-latino, el arte toscano y el arte oriental, predominando en él el elemento hebraico, toman decididamente asiento en la literatura castellana" 75 . Frente a la italiana o "clásica", de Boscán y Garcilaso, o la "escuela tradicional castellana” de Castillejo, Revilla resalta la "gran importancia para el desenvolvimiento de la literatura patria [...] de la escuela oriental, llamada también sevillana", que tuvo a Herrera por cabeza —y a Mal Lara por iniciador de su primera etapa $-{ }^{76}$. Revilla combina abigarradamente fuentes y criterios para explicar la esencia de esa escuela oriental capitaneada por el Divino; en su comentario remite a la teoría del dialecto poético y las tesis arabistas:

La influencia del Renacimiento, que dio impulso a todos los estudios, y muy particularmente las raíces que en nuestro suelo habían echado desde los tiempos del rey Sabio el arte simbólico-oriental de los árabes y de los indios, así como los estudios bíblicos a que dieron mayor preponderancia las cátedras establecidas en Sevilla para estudiar las obras escritas en lengua arábiga, todo contribuyó a la formación de la lengua poética a que nos referimos, cuyo carácter predominante es el de reflejar el genio de los orientales mediante la

parar el orientalismo español de la influencia arábiga que habían defendido los liberales románticos: "no atribuimos a la literatura árabe la injustificada influencia que se le ha concedido en los orígenes de la española", lo que no significa negarle el "haberla enriquecido" (José Amador de Los Ríos, Historia crítica de la literatura española, Madrid, Rodríguez, 1861-1865, vol. 5, p. 167).

74 Ángel Lasso de la Vega y Argüelles, op. cit., p. 24.

75 Manuel de la Revilla, Principios de literatura general e Historia de la literatura española, Madrid, Tipografía del Colegio Nacional de Sordomudos y de Ciegos, 1872, 2 vols., vol. I, p. 11.

76 Ibidem, p. 26. 
propagación que en nuestro suelo habían tenido la literatura sarracena. Prestábase en gran manera a esta nueva dirección de la poesía la imaginación exuberante de los andaluces exaltada, como dice el Sr. Amador de los Ríos [...]. El genio y la fantasía de los árabes estaban fuertemente arraigados y florecían como en tierra propia [...]; por lo que no es de extrañar, antes debe considerarse como natural y lógico, que el lenguaje poético en cuyo favor tanto hizo Garcilaso, adquiriese mas pompa, elevación, armonía y grandeza y se hiciese fantástico y fogoso manejado por los poetas de la escuela sevillana ${ }^{77}$.

La difusión durante los años setenta y ochenta del siglo XIX de esa imagen de Herrera como jefe de una escuela poética oriental puede comprobarse en la breve historia de la literatura española del Diccionario universal de la lengua castellana $(1878)^{78}$, o en la Historia compendiada de la literatura Española de Salvador Arpa, que dedica la "Lección 23" a la "Escuela oriental o sevillana", de la que "Herrera es gloria [...], a la vez que tenido por padre y fundador". Desarrollando la tesis de Revilla, Arpa distingue para la escuela un primer periodo (el de Mal Lara y sus discípulos, entre los que incluye a Diego Girón, Fernando de Medina, Pacheco, Cristóbal Tamariz, Fernando de Cangas, Juan Sáez de Zumeta) y un segundo periodo de esplendor, con Herrera al frente. De hecho, a él se debe el título de la escuela, que recibió "el nombre de oriental por la imitación hebraica que [él] fue el primero en introducir en la lírica española"79. El Herrera de Arpa mantiene muchas

77 Ibidem, pp. 26-27.

78 La entrada "La literatura en Espańa" enumera las escuelas poéticas principales: "la alegórica o dantesca; la escuela italiana o petrarquista, la escuela tradicional castellana, opuesta a la anterior; la escuela clásico salmantina y clásica aragonesa; la escuela oriental o sevillana; la escuela conceptista o clásica degenerada, y la culterana u oriental degenerada, y la escuela clásico-oriental”, sin dejar de notar como característica de nuestra tradición literaria "un tinte oriental muy subido, y por lo tanto, una gran tendencia a lo maravilloso, a las metáforas y a la pompa del lenguaje" (Nicolás María Serrano (dir.), Diccionario universal de la lengua castellana: ciencias y artes, Madrid, Biblioteca Universal Ilustrada, 1878, p. 1225).

79 Salvador Arpa y López, Historia compendiada de la literatura Española, Madrid, Sucesores de Rivadeneyra, 1889, pp. 145-146. Todavía a mediados del siglo XX la ecuatoriana Nueva historia crítica de la literatura española de Sergio Núñez dedica un capítulo a la "Escuela sevillana u oriental", en el que repite a Revilla y Arpa, insistiendo en que "ninguna escuela poética como ésta se presenta más definida y caracterizada, por las 
de las contradicciones que ha venido arrastrando su imagen a lo largo del siglo, y que no dejan de ser un reflejo de aquellos preliminares de Versos de 1619, de los que Arpa copia una parte del prólogo de Rioja.

Como bien señala Arpa, "[a]unque los críticos están unánimes en reconocer que Herrera elevó a su más alto grado la lírica espańola, disienten respecto a las dotes y cualidades que adornan a este poeta, así como al mérito de sus principales obras", pues "al lado de esa magnificencia de versificación, de esos giros nuevos que inventó y de esas frases atrevidas y llenas de pompa y de armonía, aparece sacrificada la sencillez sublime de sus antecesores y abierta la puerta a una afectación y obscuridad precursora del culteranismo" $"$.

Pero al señalar el principal demérito herreriano, Arpa no remite en absoluto a los argumentos del siglo XVII ni al debate sobre el papel de Herrera en los prolegómenos del gongorismo, sino a un criterio mucho más innovador: "de lo dicho, sacamos una consecuencia [...] que es la siguiente: de ser la poesía lo que indica Rioja, deja de ser popular, y queda su estudio, como lectura y placer reservado a unos pocos literatos y eruditos" ${ }^{\prime 1}$. Herrera no puede ser un poeta moderno, en el sentido de un poeta actual. Es lo mismo que había defendido Campoamor, que cuando se refiere a "el señor Lista y todos los discípulos de la escuela rimbombante bélico-oriental" "82 hacía referencia a la beligerancia con que el grupo sevillano defiende sus posiciones, a su pomposo dialecto poético, y al imaginario con que entonces se asociaba Oriente: artificiosidad alambicada, refinamiento recargado, afectación. Pero también a una denominación que para entonces se había ya codificado en las historias literarias: la "escuela oriental o sevillana", de la que Herrera es su principal representante y Lista y sus discípulos defensores, difusores y continuadores. El orientalismo de Herrera no coincidía, para estos autores, con los valores de primitivismo y desnudez, sino con una galanura exuberante que ya no resultaba tan atractiva, dado el rumbo de la lírica española hacia la simplicidad retórica.

circunstancias favorables que contribuyeron a su formación" (Sergio Núnez, Nueva historia crítica de la literatura española, Quito, Progreso, 1957, p. 179).

80 Ibidem, pp. 146-147.

81 Ibidem, p. 147.

82 Ramón de Campoamor, prólogo a Nubes y flores (1873) de Fernando Martínez Pedrosa. El prólogo fue recogido posteriormente en su Poética, op. cit., pp. 109-110. 
Arpa hacía alusión a algo que ya se ha apuntado: esa tendencia oriental de la poesía española (aunque también para explicar la singularidad de la narrativa se remitía, empezando por los hispanistas ingleses, a la influencia arábiga ${ }^{83}$ fue muchas veces considerada un peligro, en el sentido de que podía servir de estímulo a la mayor peste de nuestra tradición lírica: el gongorismo. Donoso Cortés afirma en un discurso de 1829 que "Góngora, cuando no delira, se viste con toda la pompa oriental de la musa castellana" ${ }^{44}$, lo que implica el reconocimiento de esa tendencia propia de nuestra poesía y su vinculación con la pomposidad.

Curiosamente fue uno de "los discípulos de la escuela rimbombante bélico-oriental" —usando los términos de Campoamor-, en concreto aquel que había criticado en duros términos las Doloras, quien formuló más explícitamente esta conexión entre el orientalismo espańol y la tendencia cuyo más alto grado representaba Góngora. En las "Observaciones acerca de Góngora y del culteranismo en España”, Manuel Cañete, otro discípulo sevillano de Lista, traza una línea de continuidad entre ese "genio" oriental de los espańoles, la corrupción y exageración y el delirio literario de la escuela gongorina:

Más de una vez y por más de un escritor se ha dicho que el genio de los espańoles, fácil a la exageración y amante del lujo de colorido, debió al comercio con los árabes apasionarse con ardor de las pompas del Oriente; y que en este rasgo peculiar de nuestro carácter poético estriban las diferencias que existen entre la poesía castellana y la de otros pueblos de Europa. Tal observación es incompleta. [...] Lo que hay de cierto es que los pueblos corrompidos, lo mismo que los hombres estragados, no se satisfacen con cosas naturales y buscan en la exageración sensaciones nuevas. Por eso vemos que recurren a las fuentes menos puras y aspiran al lauro de innovadores,

83 También Adolfo de Castro cree que "los que escribieron libros de caballerías [...] imitaron en sus obras los cuentos asiáticos [...] remedando el estilo oriental con atrevidísimas metáforas". Vid. Adolfo de Castro, "Discurso sobre los plagios que de comedias y novelas espańolas del siglo XVII cometió M. Le Sage”, en Poesías de D. Pedro Calderón de la Barca, con anotaciones, op. cit., pp. 103-122 (pp. 120-121).

84 Juan Donoso Cortés, "Discurso de apertura en Cáceres" [1829], en Obras completas de D. Juan Donoso Cortés, ed. Hans Juretschke, Madrid, Editorial Católica, 1946, vol. I, pp. 23-46 (p. 41). 
precisamente cuando, roto el freno de la razón, se abandonan a los mayores delirios. Además, la afición a la grandilocuencia, a la hipérbole, a la profusión de imágenes, a la intemperancia metafórica, no es solo patrimonio del Oriente, sino de los pueblos meridionales. ${ }^{85}$

$\mathrm{Su}$ tesis coincide con lo que los preliminares de Versos habían querido insinuar y tantos críticos después repetido: "Góngora, lejos de crear lo que ya existía cuando él hubiera podido crearlo, se contentó con ensanchar y sistematizar elementos que andaban diseminados o en naciente desarrollo" 86 , y, según Cañete, "[b]asta, efectivamente, ver [...] la pompa, a veces extremada, de Herrera, para predecir las nebulosas exornaciones de Góngora" ${ }^{87}$. En aquella moda influyó la peste de la escuela de Marino -Cañete no hace sino repetir la conocida inculpación-, pero el origen último parece encontrarlo en esa manera orientalista que afectaba, como dice, a todos los pueblos meridionales. En la exhaustiva demarcación por escuelas poéticas de sus Principios de literatura general e Historia de la literatura española, Revilla incluso confeccionó un título para la peor heredera de la escuela oriental de Herrera:

los cultos convirtieron en hinchado, ampuloso y metafórico, hasta rayar en lo absurdo y extravagante, exagerando el lenguaje poético

85 Manuel Cañete, "Observaciones acerca de Góngora y del culteranismo en España", Revista de Ciencias, Literatura y Artes, (1855), pp. 317-342 (p. 321-322). El artículo fue editado en Revue Hispanique, XLVI (1919), pp. 281-311. Vid. Donald Allen Randolph, Don Manuel Cañete, cronista literario del romanticismo y del posromanticismo en España, Chapel Hill, University of North Carolina Press, 1972, pp. 175-179, donde cuenta cómo fue Cañete coleccionando largamente noticias de Góngora hasta preparar estas "Observaciones".

86 Manuel Cañete, op. cit., pp. 317-342 (p. 334).

87 Ibidem, p. 321. La idea está repetida en muy distintos lugares del artículo: "Hasta en Fernando de Herrera se suelen encontrar asomos del amaneramiento gongorino", (Ibidem, p. 334); "En el mismo Fernando de Herrera ¿no se ven rasgos que preludian la bastarda degeneración del siglo XVII?”, (Ibidem, p. 337); “¿No se hace oscuro en ciertos pasajes, por el prurito de engolfar se en alusiones mitológicas? Queriendo dar novedad a la elocución pintoresca, ¿̨no se arroja, en la composición últimamente citada, a llamar al cielo estrellado claustro? El deseo de ennoblecer la estructura de la frase, ¿no le lleva a chocar en trasposiciones como la del verso: 'Y le digo señora dulce mía?" (Ibidem, p. 338). 
de Herrera (que sus discípulos, y aun él mismo habían ya inclinado por esta pendiente), por eso no parecerá paradójico que señalemos como origen del culteranismo la versificación misma del gran poeta sevillano; de aquí el que también distingamos la escuela que ahora nos ocupa con el nombre de oriental degenerada ${ }^{88}$.

El argumento orientalista ha seguido presente en la hispanística extranjera hasta el siglo XX, y así Peers encuentra la peculiaridad del Romanticismo español en que la "[v]aguedad, indeterminación de forma, amor al misterio" románticas vienen acompañadas de una verbosidad y "unida[s] a una grandilocuencia que no alcanzan los románticos de ningún otro país", como en el caso de Zorrilla, que reproduce el "estilo oriental" 89. Esa misma grandilocuencia de nuestro románticos, según Blanco García, "en lo malo no tiene nada que envidiar el culteranismo del siglo XVII"90.

Estos últimos apuntes demuestran el éxito de este imaginario interpretativo: culteranismo y romanticismo quedaban hermanados por esa tendencia española hacia el orientalismo, marca que desde la historización literaria de Schlegel intentó asociarse a nuestra identidad cultural y literaria. Herrera tenía en esa narrativa un papel protagonista.

\section{Herrera, poeta cristiano}

Si los rasgos sublimes y orientales que algunos quisieron descubrir en parte de su poesía concentraron gran parte de los encomios a Herrera,

88 Manuel de la Revilla, op. cit., p. 29. Frente a esa degeneración de la escuela oriental, Revilla pondera el papel de la escuela que trató de "armonizar" los principios "de las dos que a la sazón predominaban (la clásica y la oriental). [...] Sin olvidar el espíritu y sentido moral ni aun la forma del clasicismo, la escuela a que nos referimos completa y modera, embelleciéndolo, el sistema poético de los orientalistas sevillanos, por lo que creemos que su nombre debe ser el de escuela clásico - oriental o armónica. Su jefe es Francisco de Rioja, a quien ayudan en tan noble empresa Rodrigo Caro, Juan de Arguijo y Pedro Quirós, con algún otro de menor importancia” (Ibidem, p. 33).

89 Edgar Allison Peers, Historia del movimiento romántico español, Madrid, Gredos, 1973, vol. II, p. 384 [1 $1^{\text {a }}$ ed. 1954].

90 Francisco Blanco García, La literatura española en el siglo XIX, Madrid, Sáenz de Jubera, 1899, 3 vols., vol. I, p. 181. 
otra de las posibilidades de romantizarlo y así atraerlo hacia los nuevos criterios de valoración fue acentuar su condición de poeta cristiano. Con ello asumía otra de las marcas de la identidad española que construyeron los románticos, empezando por Schlegel, y continuaron sus muchos seguidores. Entre ellos Böhl de Faber, aunque no solo: como han estudiado Juretschke y Flitter, las ideas schlegelianas tuvieron un extraordinario eco en el ambiente español de los años treinta y cuarenta del siglo XIX ${ }^{91}$.

El Romanticismo español fue claramente partidario de la "despaganización" literaria: si la oda de Núñez y Díaz de 1805 titulada "Las bellezas poéticas del cristianismo sobre las de la gentilidad" combina el estro sublime de Píndaro con la defensa de la musa cristiana, la reseńa citada a las Poesías de Lista señala que "la senda [...] erótica o amatoria [...] está ya muy trillada y apenas puede hacerse otra cosa que seguir las huellas de los que marcharon delante", por lo que el autor prefiere "la imitación del estilo oriental" de la poesía religiosa, donde se advierte "grande majestad y elevación de estilo [...], riqueza de imágenes y sobre todo mucha variedad de comparaciones ingeniosas" 92 .

Por su parte, Virués reclamaba adaptar la épica clásica, griega y latina a la historia nacional y despaganizarla ${ }^{93}$. Herrera podía ser en ello un buen modelo, como poeta épico cristiano de resonancias bíblicas; de hecho, Lista lo había puesto a la par que Milton: ambos son demostraciones del "carácter de la poesía oriental" al que dedicaba el artículo citado y en el que aconseja "a los autores modernos cierta imitación de lo hebraico, sobre todo cuando se escriben poesías de asuntos sagrados o religiosos" 94 .

En Herrera, según el anónimo autor del folleto sevillano, orientalismo y religiosidad son rasgos conectados, y así pide a sus lectores: "Nótese en

91 Hans Juretschke, "El problema de los orígenes del Romanticismo español", en Historia de España fundada por Ramón Menéndez Pidal, Tomo XXV. La época del romanticismo (1808-1874), Vol. 1: Orígenes; Religión; Filosofía; Ciencia, Madrid, Espasa Calpe, 1989, pp. 3-209; y Derek Flitter, "La reafirmación de los principios schlegelianos en la crítica literaria”, en Teoría y crítica del romanticismo español, Cambridge, Cambridge University Press, 1995, pp. 148-181.

92 "Literatura. Poesías de D. Alberto Lista", op. cit., pp. 3-4 (p. 4).

93 José Joaquín de Virués, op. cit., pp. 86-87.

94 Rubén Benítez, "Bécquer y la poesía hebraica”, en Estudios de literatura española de los siglos XIX y XX: homenaje a Juan María Díez Taboada, ed. Miguel Ángel Garrido Gallardo, Madrid, CSIC, 1998, pp. 31-37 (p. 33). 
nuestro poeta un orientalismo que da algunas veces a su lenguaje poético cierto sabor austero, sencillo y místico" 95 . El Herrera seguidor de la tradición bíblica servía para ensalzar las novedades del orientalismo y la reivindicación de la España de las tres culturas (tan del gusto del primer liberalismo), sin dejar de mantener la idea de la España siempre poéticamente cristiana.

José Fernández Espino, en la introducción al mencionado Curso histórico-crítico de la literatura española, hace suya la caracterización de "la literatura española [como] hija principalmente de tres grandes sentimientos, el religioso, el caballeresco y el de la galantería" 96 . El primer atributo lo cumple con creces Herrera, que en su "lira religiosa [...] había puesto cuidadoso esmero [...] en todo cuanto pudiera darles elevación, arrebato y armonía: así en sus manos parece que baja directamente del Sinaí, o que en ella se escucha la inspirada voz de algún Profeta". Mientras, su "lírica pagana", en "arrebatada inspiración” y "poseíd[a] de fuego divino", "da lecciones a los pueblos en máximas profundas, que se escuchaba en las plazas, en los templos, al frente de los ejércitos para animarlos al combate, [...] y pintaba con frase ardiente los triunfos de la patria"97.

Las palabras de Quintana resuenan tras estas de Fernández Espino, que vuelve a ensalzar el modelo de Herrera en un artículo recogido en sus Estudios de literatura y de critica de 1862 (pero probablemente anterior) y titulado "Armonía entre la razón y la religión católica”. En este caso, el Herrera pagano, incluso el arrebatado y sublime que pintaba en el Curso apoyándose en Quintana, no alcanza en ningún caso la extraordinaria misión que asumía como poeta cristiano:

Consideremos también la poesía lírica pagana. Observemos al vate poseído de ardorosa exaltación por la gloria de su patria, elevándose sobre cuanto le cerca, pintando con frase de fuego sus triunfos y dando lecciones a los pueblos en máximas profundas [...] ¿Pueden, sin embargo, compararse sus sentimientos con los altísimos de la poesía lírica cristiana, ni el poder de Júpiter, esclavo del amor sensual y del destino, ni las rencillas domésticas de su Olimpo, con el poder del Omnipotente y con la santidad y pureza suma del cielo cristiano?

95 "Fernando de Herrera", op. cit., p. 242.

96 José Fernández Espino, Curso histórico-crítico, op. cit., p. IV.

97 Ibidem, p. 702. 
Leamos á Píndaro, cuyo arrebato y fogosidad son envidia del vate de Venusa [...]. Leamos al mismo Horacio [...]. Pues bien, comparemos esta poesía con la lírica cristiana, y, limitándonos para gloria nuestra a la nación española, dígase si alguno de los dos supera al cantor de la batalla de Lepanto en la forma poética, y si le igualan en la majestad imponente del pensamiento. [...] Cítesenos el pasaje de mayor pompa y solemnidad que se encuentre en los dos poetas líricos paganos, y se verá si puede competir con el siguiente, principio de la oda a tan famosa batalla: "Cantemos al Señor que en la llanura [...]". Oigamos también otro pasaje del mismo autor, tomado de la canción a la pérdida del rey D. Sebastián [...]. ¡Cuántos rasgos pudieran copiarse en esta y otras composiciones del mismo autor de igual majestad y fuego! Obsérvese que la entonación grandilocuente y el mayor arrebato lírico de Herrera, aunque hombre siempre de alto pensamiento, se encuentran en aquellos períodos en que invoca el influjo divino, o aparece enalteciendo al que le implora y reverencia, y desatando los raudales de su ira contra el descreído que le ultraja ${ }^{98}$.

Probablemente Fernández Espino debió conocer un artículo anterior al suyo de Joaquín José Cervino, titulado "De las tendencias y carácter que debiera tomar la poesía en nuestra época” y publicado por la Revista de Europa en 1846. Fue escrito en esos mediados de siglo en los que, como bien dice su autor, Romanticismo y Clasicismo han ido agotando sus propuestas y no se descubría senda por la que continuar. Cervino hace una propuesta que coincide con la tendencia piadosa del Biedermeier espańol (afín al pensamiento de Fernández Espino): la senda de la poesía la mostrará Dios, “[so]lo el que es autor de cuanto vive nos lo podrá proporcionar: Dios debe ser el alma de nuestra desfalleciente poesía"99.

98 José Fernández Espino, "Armonía entre la razón y la religión católica", en Estudios de literatura y de crítica, Sevilla, Imprenta de La Andalucía, 1862, pp. 267-330 (pp. 292-294).

99 Y sigue: "Si tiene a Dios por objeto, si con él y por él respira, ataviada con cualquier ropaje marchará noble, graciosa y encantadora; pero si se desvía de esta senda, si olvida que es la mas hermosa de las hijas del cielo, bajada a vivir entre los hombres solo para cantar las glorias del Criador en la lengua de los ángeles, entonces por mas que la cubramos con púrpura y oro, no será mas que un cadáver suntuosamente adornado, del que en breve tendríamos que apartar la vista mas que con fastidio, hasta con horror" (Joaquín José Cervino, "De las tendencias y carácter que debiera tomar la poesía en nuestra época", Revista de Europa, periódico quincenal de ciencias, literatura y artes (1846), pp. 216-223 (p.218)). 
La base del argumento es romántica y tiene claras raíces en Schlegel: cada pueblo ha creado una literatura basada en sus creencias y en su fe, así que "nuestra poesía debe exhalar, por decirlo así, el perfume de la religión de sus autores, como la poesía de Homero y de Virgilio exhalaba el de la suya" ${ }^{100}$. Si los poetas españoles, en vez de entregarse a la imitación y escoger como asunto la gentilidad, hubiesen preferido cantar la musa cristiana, su voz hubiera sido mucho más auténtica; para ello contaban con la ventaja de que "nuestro carácter, nuestro genio, nuestra índole y nuestro idioma, se acomodan tan maravillosamente a los giros y esencia de la poesía oriental", por lo que "preciso es convenir en que la Biblia debe ser para nuestra literatura poética lo que hasta aquí han sido las obras de Homero y de Anacreonte, de Virgilio y de Tibulo" ${ }^{101}$. Hace así una invitación a usar de la Biblia como tesoro argumental (él mismo fue autor de un drama histórico —en verso — titulado Sara, de asunto bíblico, que se publicó en 1848) y pone a Herrera como ejemplo de éxito:

en nadie como en el divino Herrera se nota el efecto de lo que llevamos dicho: mientras imitó los modelos de la poesía griega y latina, su extremado talento escribió odas tan acabadas como la que dedicó a D. Juan de Austria [...]. Mas, cuando olvidado de copiar los originales de Grecia y Roma, se dejó inspirar por su religión, y acudió a beber raudales de poesía en el fecundísimo manantial de ese gran libro, donde la beberían los ángeles si de ello tuviesen necesidad, entonces Herrera se excedió a sí mismo, llenó de pasmo al mundo literario, de orgullo a las letras españolas, de satisfacción a los amantes de la religión cristiana, y escribió la canción "A la batalla de Lepanto", que le valió nada menos que el epíteto de divino que la posteridad entusiasmada añadió a su nombre inolvidable mientras exista una sombra siquiera de literatura en nuestro suelo ${ }^{102}$.

Cervino añade una demostración comparativa entre ambas odas, afirmando que, aunque "las dos son escritas por un mismo autor, las dos en una misma lengua, las dos para celebrar un muy parecido acontecimiento", la diferencia de que "en la primera no entran para nada las creencias

100 Ibidem, p. 218.

101 Ibidem, p. 222.

102 Ibidem, p. 220. 
religiosas del poeta mientras que en la segunda son el todo" obra el milagro que las distingue: "y dígasenos [...] si la imitada de Horacio no se queda a inmensísima distancia de la imitada de la Biblia”. El milagro, sin embargo, no es obra divina, sino que remite a uno de los argumentos más humanos entre los criterios que trajo el Romanticismo y que acabamos de ver (empleado con variantes) en Salvador Arpa: la obra que remite a la tradición grecolatina exige un lector culto e invita a una lectura erudita; la oda cristiana apela a nuestros sentimientos, a nuestra tradición, a la fe de los lectores, a una experiencia lectora inmediata, no dirigida por el intelecto ni mediatizada por la erudición: "si para entender aquella es necesario ser erudito, [...] para dejarse arrebatar con esta solo es menester haber nacido en nuestra nación después de formada su lengua"103. De la una, la mayoría de los lectores no conocerá las fábulas a las que remite; sin embargo, el principio de la canción "A la batalla de Lepanto" encantará y arrebatará a los españoles, "sin duda alguna, porque dejan entender su espíritu y conocer a los personajes que en ellos son mencionados”.

Resulta significativo que acabe lamentando lo que Lista por otros motivos había lamentado también: “iLástima grande que en este género no escribiese Herrera más que esta canción y otra a la pérdida del rey D. Sebastián, y mayor todavía que en él no le hayan imitado los poetas posteriores!" 104 . Herrera vuelve a presentarse de nuevo como motivo de imitación: ya no por ser modelo clásico, tampoco por ser modelo de sublimidad, sino como poeta cristiano.

El Herrera de influencia hebraica, celebrado con entusiasmo desde finales de la Ilustración y considerado el más auténtico y verdadero por la crítica de la época, sirvió a la primera historiografía romántica para confirmar la naturaleza oriental de la literatura española. La imitación de los poemas bíblicos que practicó en algunas de sus odas se interpretó al margen de su contexto original para contaminarse por conceptos del incipiente historicismo literario y los paradigmas identitarios nacionales. Desde el punto de vista histórico, aquella imitación podía confirmar la influencia matriz hebrea e incluso el sustrato árabe de nuestra tradición poética. Desde el punto de vista patriótico, era marca de la identidad singular de la poesía espańola o andaluza, tanto por su orientalismo como por la pujanza de su musa cristiana.

103 Ibidem, p. 221.

104 Ibidem, p. 221. 